\title{
Estradiol Negatively Modulates the Pleiotropic Actions of Orphanin FQ/Nociceptin at Proopiomelanocortin Synapses
}

\author{
Amanda Borgquist ${ }^{a}$ Malika Kachani ${ }^{b}$ Nadia Tavitian ${ }^{a}$ Kevin Sinchak ${ }^{c}$ \\ Edward J. Wagner ${ }^{\mathrm{a}}$ \\ ${ }^{a}$ Department of Basic Medical Sciences, College of Osteopathic Medicine, and ${ }^{b}$ College of \\ Veterinary Medicine, Western University of Health Sciences, Pomona, Calif., and ${ }^{\mathrm{C}}$ Department of \\ Biological Sciences, California State University Long Beach, Long Beach, Calif., USA
}

\section{Key Words}

Estradiol · Proopiomelanocortin · Orphanin FQ · Opioid receptor-like $1 \cdot \mathrm{G}$ protein-gated, inwardly rectifying $\mathrm{K}^{+}$ channel. Glutamate

\begin{abstract}
Orphanin FQ/nociceptin (OFQ/N) inhibits the activity of proopiomelanocortin (POMC) neurons located in the hypothalamic arcuate nucleus (ARH) that regulate female sexual behavior and energy balance. We tested the hypothesis that estradiol modulates the ability of OFQ/N to pre- and postsynaptically decrease the excitability of these cells. To this end, whole-cell patch-clamp recordings were performed in hypothalamic slices prepared from ovariectomized rats, including some that were injected with the retrograde tracer Fluorogold in the medial preoptic nucleus (MPN) to label the POMC neurons regulating sexual receptivity. OFQ/N (1 $\mu \mathrm{M})$ evoked a robust outward current in ARH neurons from vehicle-treated animals that was blocked by the opioid receptorlike (ORL)1 receptor antagonist UFP-101 (100 nM) and the $\mathrm{G}$ protein-gated, inwardly rectifying $\mathrm{K}^{+}$(GIRK-1) channel blocker tertiapin (10 nM). OFQ/N also produced a decrease in the frequency of glutamatergic, miniature excitatory postsynaptic currents (mEPSCs), which was also antagonized by UFP-101. Estradiol benzoate $(2 \mu \mathrm{g})$ increased basal mEPSC frequency and markedly diminished both the OFQ/N-in-
\end{abstract}

duced activation of postsynaptic GIRK-1 channel currents and the presynaptic inhibition of glutamatergic neurotransmission. These effects were observed in identified POMC neurons, including eight that projected to the MPN. Taken together, these data reveal that estradiol attenuates the pleiotropic inhibitory actions of OFQ/N on POMC neurons: presynaptically through reducing the OFQ/N inhibition of glutamate release and postsynaptically by reducing ORL1 signaling through GIRK channels. As such, they impart critical insight into a mechanism for estradiol to increase the activity of POMC neurons that inhibit sexual receptivity.

Copyright $\odot 2013$ S. Karger AG, Basel

\section{Introduction}

Orphanin FQ (a.k.a., nociceptin $(\mathrm{OFQ} / \mathrm{N}))$ is a heptadecapeptide that activates a metabotropic, $\mathrm{G}_{\mathrm{i} / \mathrm{o}}$-coupled receptor termed the opioid receptor-like (ORL)1 receptor [1-3]. Being $G_{i / 0}$-coupled, the ORL1 receptor regulates cell excitability by augmenting postsynaptic $\mathrm{K}^{+}$currents, decreasing postsynaptic $\mathrm{Ca}^{2+}$ currents, and presynaptically inhibiting neurotransmitter release. For example, OFQ/N elicits an ORL1 receptor-mediated activation of $\mathrm{G}$ protein-gated, inwardly rectifying $\mathrm{K}^{+}$(GIRK) currents in the locus coeruleus [4], periaqueductal gray [5], nucleus raphe magnus [6], as well as the ventromedial (VMN)

\section{KARGER}

E-Mail karger@karger.com

www.karger.com/nen
(C) 2013 S. Karger AG, Basel

0028-3835/13/0981-0060\$38.00/0
Edward J. Wagner

Department of Basic Medical Sciences

College of Osteopathic Medicine, Western University of Health Sciences

309 E. Second Street, Pomona, CA 91766 (USA)

E-Mail ewagner@westernu.edu 
$[7,8]$, suprachiasmatic (SCN) [9], tuberomammillary [10] and arcuate (ARH) $[7,11,12]$ nuclei of the hypothalamus. OFQ/N also inhibits voltage-gated, L- and Ntype $\mathrm{Ca}^{2+}$ currents in hippocampal neurons [13], T-type currents in the dorsal root ganglion cells [14] and $\mathrm{N}$ - and $\mathrm{P} / \mathrm{Q}$-type currents in the SCN [15]. In addition, OFQ/N presynaptically inhibits excitatory glutamatergic input in the ARH $[7,12]$ as well as both glutamatergic and inhibitory $\gamma$-aminobutyric acid (GABA)ergic input in the SCN [15] and lateral amygdala [16].

While it is clear that the ORL1 receptor is distributed throughout the central nervous system, its expression is particularly abundant in the hypothalamus $[1,17,18]$. In situ hybridization and OFQ/N-stimulated $\left[{ }^{35} \mathrm{~S}\right] \mathrm{GTP} \gamma \mathrm{S}$ binding studies have revealed intense ORL1 expression in the medial preoptic nucleus (MPN), paraventricular nucleus, $\mathrm{ARH}$ and $\mathrm{VMN}[1,17,18]$. Accordingly, OFQ/N is thought to play an important role in regulating functions controlled by the hypothalamus like energy balance and reproduction $[19,20]$. Regarding the latter, the current available evidence implicates OFQ/N in mediating ovarian steroid-induced changes in female sexual behavior [20,21]. Sexual receptivity (as assessed using lordosis) is modulated via a hypothalamic-limbic circuit comprising the VMN, the ARH, the medial amygdala and the MPN [21-23]. One of the most important neuroanatomical substrates within this circuit is the subpopulation of proopiomelanocortin (POMC) neurons that have cell bodies in the ARH and project to the MPN. These cells release the endogenous opioid peptide $\beta$-endorphin that activates $\mu$-opioid receptors expressed on MPN neurons. Estradiol has long been known to increase the release of $\beta$-endorphin during the follicular period of the primate ovarian cycle [24], and when administered to ovariectomized rodents and primates it increases $\beta$-endorphin expression [25] and release [22,24]. Thus, estradiol rapidly activates this circuit to stimulate release of $\beta$-endorphin from ARH POMC neurons in the MPN to activate $\mu$-opioid receptors and inhibit sexual receptivity $[21-23,26,27]$. This estrogenic effect is a requisite step for the subsequent development of sexual receptivity $[22,23]$.

Estradiol has been shown to rapidly negatively modulate the coupling of inhibitory metabotropic receptors to their effector systems in hypothalamic neurons. For example, in POMC neurons estradiol attenuates the activation of postsynaptic GIRK channels elicited by stimulation of $\mathrm{G}_{\mathrm{i} / \mathrm{o}}$-coupled $\mu$-opioid and $\mathrm{GABA}_{\mathrm{B}}$ receptors [28$30]$, as well as the activation of postsynaptic Kv4.2 channels caused by stimulation of cannabinoid CB1 re- ceptors $[31,32]$, in a rapid and sustained fashion. Estradiol also diminishes the CB1 receptor-mediated presynaptic inhibition of glutamatergic input to these cells [32, 33 . Given that $\mathrm{OFQ} / \mathrm{N}$ inhibits the considerable majority of ARH neurons, including POMC neurons [7, 11, 12], and that it plays a role in mediating ovarian steroid-induced changes in female sexual behavior through ARH POMC neurons that project to the MPN [20,21,23], we tested the hypothesis that estradiol reduces the pre- and postsynaptic ORL1 receptor-mediated actions that inhibit the excitability of these cells.

\section{Materials and Methods}

\section{Animals}

Adult Long-Evans female rats (200-225 g) were purchased from Charles River Laboratory, Inc. (Wilmington, Mass., USA). Bilateral ovariectomies (OVX) were performed by the supplier. Animals were housed in a climate- and light-controlled room (12/12 L/D cycle, lights on 07:00 h) with food and water available ad libitum. All procedures were approved by the Western University of Health Sciences IACUC in accordance with institutional guidelines based on $\mathrm{NIH}$ standards. Animals were treated once every 4 days for three cycles with either estradiol benzoate (EB; $2 \mu \mathrm{g}$, s.c.) or its sesame oil vehicle $(0.1 \mathrm{ml}$ total volume, s.c.). Brains were collected $30 \mathrm{~h}$ after the final EB/vehicle treatment. This treatment paradigm mimics the peak levels of estradiol that are produced on the afternoon of proestrus and does not facilitate sexual receptivity without subsequent progesterone or pharmacological manipulation [21, 23, 26, 34, 35]. Further, this estradiol priming paradigm activates the inhibitory ARH-MPN reproductive behavior circuit while priming other mechanisms that are involved in the facilitation of lordosis and has been used by us and others to study the physiology of steroid regulation of female sexual receptivity and feeding [18, 27, 34-36].

\section{Drugs}

Unless otherwise indicated, all drugs were purchased through Tocris Cookson, Inc. (Ellisville, Mo., USA). EB (Steraloids, Newport, R.I., USA) was initially prepared as a $1-\mathrm{mg} / \mathrm{ml}$ stock solution in punctilious ethanol. A known quantity of this stock solution was added to a volume of sesame oil sufficient to produce a final concentration of $20 \mu \mathrm{g} / \mathrm{ml}$ of EB. OFQ/N, the ORL1 receptor antagonist UFP-101, the voltage-gated $\mathrm{Na}^{+}$channel blocker tetrodotoxin (TTX) with citrate (Alomone Labs Ltd, Jerusalem, Israel), the GIRK channel blocker tertiapin (Alomone Labs Ltd), the $\mathrm{GABA}_{\mathrm{A}}$ receptor antagonist 6-imino-3-(4-methoxyphenyl)-1(6H)-pyridazinebutanoic acid hydrobromide (SR 95531) and the a-amino3-hydroxyl-5-methyl-4-isoxazole-propionate (AMPA) receptor antagonist 2,3-dioxo-6-nitro-1,2,3,4-tetrahydrobenzo[f] quinoxaline-7-sulfonamide (NBQX) were dissolved in UltraPure $\mathrm{H}_{2} \mathrm{O}$ to stock concentrations of $1 \mathrm{mM}, 100 \mu \mathrm{M}, 1 \mathrm{mM}, 1 \mu \mathrm{M}, 10 \mathrm{mM}$ and 10 $\mathrm{mM}$, respectively. The $N$-methyl-D-aspartate receptor antagonist cis-4-[phosphomethyl]-2-piperidinecarboxylic acid (CGS 19755) was dissolved in $0.1 \mathrm{~N} \mathrm{NaOH}$ and diluted to the appropriate volume with UltraPure $\mathrm{H}_{2} \mathrm{O}$ (final concentration $10 \mathrm{mM}$ ). Aliquots of these stock solutions were stored at $-20^{\circ} \mathrm{C}$. 
Stereotaxic Surgery

Some animals were focally injected with the retrograde tracer Fluorogold (Fluorochrome; LLC, Denver, Colo., USA) into the MPN 6-8 days prior to experimentation. They were fitted in a stereotaxic apparatus (Digital Lab Standard; Stoelting Co., Wood Dale, Ill., USA) while under 3\% isoflurane anesthesia. The scalp was opened with a 2 - to $2.5-\mathrm{cm}$ incision made down the midline of the skull beginning at the front of the orbits towards the occipital lobe with a scalpel blade. The periosteum was rubbed from the scalp by sterile cotton swabs. A single hole was drilled so that an infusion needle could be slowly lowered into the MPN (coordinates from bregma, anterior $-0.1 \mathrm{~mm}$, lateral $-0.8 \mathrm{~mm}$, and ventral $-6.0 \mathrm{~mm}$ from dura; tooth bar $-3.3 \mathrm{~mm}$ ). The infusion needle was held at these coordinates for $1 \mathrm{~min}$ prior to the start of infusion. The retrograde tract tracer, Fluorogold ( $5 \%$ dissolved in sterile saline; 0.5 $\mu$ total volume), was slowly injected into the MPN using a Stoelting manual injector system. The infusion needle remained in place for 10 min after infusion to allow for diffusion from the tip and then slowly removed from the brain to reduce potential spread of Fluorogold. Sterile bone wax was placed in the hole to seal the cavity and help promote clotting. After surgery, the rats were given oral antibiotics in drinking water $(0.5 \mathrm{mg} / \mathrm{ml}$ of sulfamethoxazole and 0.1 $\mathrm{mg} / \mathrm{ml}$ of trimethoprim; Hi-Tech Pharmacal, Amityville, N.Y., USA) as well as Carprofen ( $5 \mathrm{mg} / \mathrm{kg}$, s.c.; Sigma Aldrich Corp., St. Louis, Mo., USA) to help control postoperative pain.

\section{Electrophysiology}

On the day of experimentation, the OVX rat was anesthetized with isoflurane, decapitated, brain removed from the skull and the hypothalamus dissected. The hypothalamic block was mounted on a cutting platform, secured in a vibratome well filled with an icecold, oxygenated $\left(95 \% \mathrm{O}_{2}, 5 \% \mathrm{CO}_{2}\right)$ artificial cerebrospinal fluid $(\mathrm{aCSF})$ in which the majority of sodium was replaced by sucrose (sucrose, 208; $\mathrm{NaHCO}_{3}, 26 ; \mathrm{KCl}, 2 ; \mathrm{NaH}_{2} \mathrm{PO}_{4}, 1.25$; dextrose, 10; HEPES, $10 ; \mathrm{MgSO}_{4}, 2 ; \mathrm{MgCl}_{2} 1 ; \mathrm{CaCl}_{2}, 1 ;$ in $\left.\mathrm{mM}\right)$. Three to four coronal slices $(300 \mu \mathrm{m})$ through the rostrocaudal extent of the $\mathrm{ARH}$ were cut at $1^{\circ} \mathrm{C}$. The slices were then transferred to an auxiliary chamber and incubated at room temperature in oxygenated aCSF containing (in $\mathrm{mM}$ ): $\mathrm{NaCl}, 124 ; \mathrm{NaHCO}_{3}, 26$; dextrose, 10; HEPES, 10; KCl, 5; $\mathrm{NaH}_{2} \mathrm{PO}_{4}, 2.6 ; \mathrm{MgSO}_{4}, 2 ; \mathrm{CaCl}_{2}, 1$. They were kept under these conditions until electrophysiological recording.

During whole-cell patch recording from ARH neurons, slices were maintained in a chamber perfused with a warmed $\left(35^{\circ} \mathrm{C}\right)$, oxygenated aCSF in which the $\mathrm{CaCl}_{2}$ concentration was raised to $2 \mathrm{mM}$. Artificial CSF and all drugs (diluted with aCSF) were perfused via a peristaltic pump at a rate of $1.5 \mathrm{ml} / \mathrm{min}$. Patch electrodes are assembled from borosilicate glass (World Precision Instruments, Sarosota, Fla., USA; $1.5 \mathrm{~mm}$ OD) pulled on a P-97 Flaming Brown puller (Sutter Instrument Co., Novato, Calif., USA), and filled with the following (in $\mathrm{mM}$ ): potassium gluconate, $128 ; \mathrm{NaCl}$, 10; $\mathrm{MgCl}_{2}$, 1; EGTA, 11; HEPES, 10; ATP, 1; GTP, 0.25; 0.5\% biocytin; adjusted to a $\mathrm{pH}$ of 7.3 with $\mathrm{KOH}$. Electrode resistances vary from 3 to $8 \mathrm{M} \Omega$. A Multiclamp 700A preamplifier (Axon Instruments, Foster City, Calif., USA) amplified potentials and passed current through the electrode. Membrane currents were recorded in voltage clamp with access resistances that typically range from 8 to $22 \mathrm{M} \Omega$, and underwent analog-digital conversion via a Digidata $1322 \mathrm{~A}$ interface coupled to pClamp 8.2 software (Axon Instruments). The access resistance, as well as the resting membrane potential (RMP) and the input resistance $\left(R_{\text {in }}\right)$, were monitored throughout the course of the recording. If the access resistance deviated greater than $10 \%$ of its original value, the recording was ended. Low-pass filtering of the currents was conducted at a frequency of $2 \mathrm{kHz}$. The liquid junction potential was calculated to be $-10 \mathrm{mV}$, and corrected for during data analysis using pClamp software.

In studies designed to evaluate the effect of OFQ/N on the firing of ARH neurons, we examined spontaneous activity in the cellattached configuration under basal conditions, in the presence of $1 \mu \mathrm{M} O F Q / N$, and during the clearance of the neuropeptide from the slice. The interspike interval was measured from at least 100 contiguous action potentials. The distributions obtained prior to and in the presence of $\mathrm{OFQ} / \mathrm{N}$ were evaluated using quantile plots and the Kolmogorov-Smirnov test.

To determine whether OFQ/N activates postsynaptic $\mathrm{K}^{+}$currents that are highly prevalent in $\mathrm{ARH}$ neurons, recordings using the whole-cell configuration from holding potentials of $-60 \mathrm{mV}$ were performed. OFQ/N was perfused along with $1 \mu \mathrm{M}$ TTX until a new steady-state holding current was established (3-5 min). Current-voltage relationships were generated before and immediately following peptide application over a range centering on the equilibrium potential for $\mathrm{K}^{+}$. This is accomplished with step command potentials ranging from -50 to $-130 \mathrm{mV}$ (1 s duration, $10-\mathrm{mV}$ increments). Blockade of the OFQ/N-induced outward current by either UFP-101 (100 nM) or tertiapin (10 nM) served as the indication that the effect was due to the activation of ORL1 receptors and GIRK-1 channels, respectively.

To evaluate if OFQ/N presynaptically inhibits glutamatergic neurotransmission at ARH synapses, we recorded miniature excitatory postsynaptic currents (mEPSCs) in the presence of both the $\mathrm{GABA}_{\mathrm{A}}$ receptor antagonist SR $95531(10 \mu \mathrm{M})$ and TTX $(500 \mathrm{nM})$ from a holding potential of $-75 \mathrm{mV}$ using an internal solution in which $\mathrm{Cs}^{+}$was substituted for $\mathrm{K}^{+}$. After collecting a 3- to 4-min segment of baseline data, we perfused OFQ/N (100 nM-1 $\mu \mathrm{M})$ for $4 \mathrm{~min}$, and then recorded mEPSCs in the presence of the peptide. The threshold for mEPSC detection was set at least $3 \mathrm{pA}$ below the baseline holding current as assessed from the headstage output, and continuously monitored throughout each 3- to 4-min recording period. Information on interval and amplitude was obtained from at least 100 contiguous mEPSCs, which we used to evaluate OFQ/Ninduced alterations in mEPSC frequency and amplitude as assessed from cumulative probability plots. We verified that the mEPSCs were due to the activation of ionotropic glutamate receptors by testing in the presence of NBQX $(3 \mu \mathrm{M})$ and CGS $19755(10 \mu \mathrm{M})$.

\section{Immunohistochemistry}

Following electrophysiological recording, slices were fixed with $4 \%$ paraformaldehyde in Sorensen's phosphate buffer ( $\mathrm{pH} 7.4)$ for 90-180 min [37]. They then were immersed overnight in $20 \%$ sucrose dissolved in Sorensen's buffer, and frozen in Tissue-Tek embedding medium (Miles, Inc., Elkhart, Ind., USA) the next day. Coronal sections $(20 \mu \mathrm{m})$ were cut on a cryostat and mounted on slides. These sections were washed with $0.1 \mathrm{M}$ sodium phosphate buffer ( $\mathrm{pH}$ 7.4) and then processed with streptavidin-Alexa Fluor (AF) 488 (Molecular Probes, Inc., Eugene, Oreg., USA) at a 1:300 dilution. After localizing the biocytin-filled neuron via fluorescence microscopy, the slides containing the appropriate sections were processed with a polyclonal antibodies directed against either $\beta$-endorphin or $\alpha$-melanocyte-stimulating hormone (Immunostar, Inc., Hudson, Wisc., USA; 1:400 or 1:200 dilution, respectively) using fluorescence immunohistochemistry [37]. 


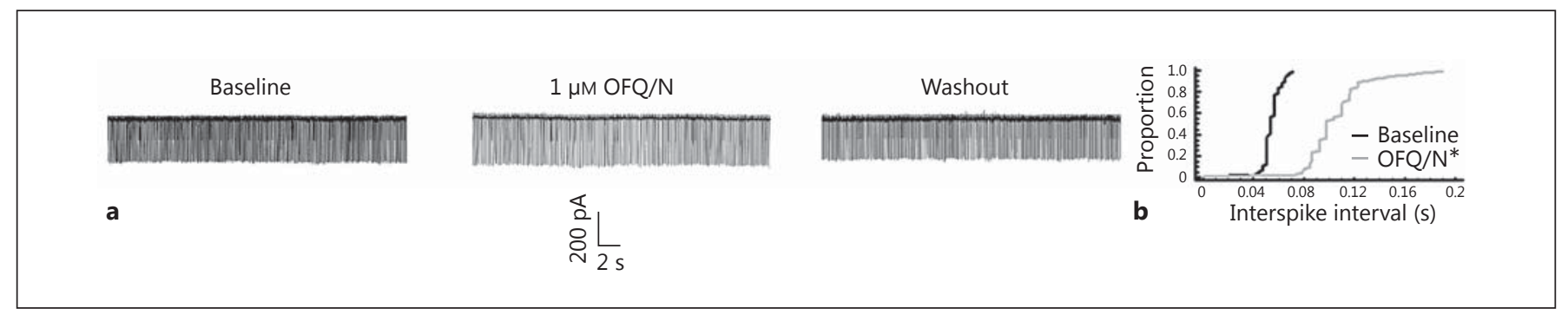

Fig. 1. $\mathrm{OFQ} / \mathrm{N}$ decreases the firing frequency of $\mathrm{ARH}$ neurons. a Membrane current tracings from an unidentified ARH cell that illustrate the reversible decrease in the number of action potentials per unit time caused by $1 \mu \mathrm{M} O F Q / N$. b A quantile plot of the in-

\section{Statistical Analyses}

Comparisons between two groups were made with either the Student's t test or the Mann-Whitney W test. Comparisons between more than two groups were performed using either the oneway, multifactorial or rank-transformed two-way analysis of variance (ANOVA) followed by the least significant difference (LSD) test, or alternatively via the Kruskal-Wallis test followed by analysis of the median-notched, box-and-whisker plot. Comparisons of the mEPSC interval distributions observed under basal and OFQ/N-treated conditions were evaluated via the KolmogorovSmirnov test. Differences were considered statistically significant if the probability of error was $<5 \%$.

\section{Results}

Recordings were made from a total of $86 \mathrm{ARH}$ neurons in slices obtained from animals $30 \mathrm{~h}$ after being treated with either EB ( $2 \mu \mathrm{g}$, s.c.) or its sesame oil vehicle. EB had no effect on either the RMP (vehicle $-52.8 \pm 1.5 \mathrm{mV}$; EB $-52.0 \pm 2.1 \mathrm{mV} ; \mathrm{n}=35-51$ ) or $\mathrm{R}_{\text {in }}$ (vehicle $525.0 \pm 79.8$ $\mathrm{M} \Omega$; EB $507.4 \pm 50.9 \mathrm{M} \Omega$; $\mathrm{n}=34-51$ ). It did, however, significantly elevate the basal mEPSC frequency (vehicle $7.8 \pm 1.2 \mathrm{~Hz}$; EB $13.7 \pm 3.0 \mathrm{~Hz} ; \mathrm{n}=5-17$; Student's t test, $\mathrm{t}=-2.13104, \mathrm{p}<0.05)$ without any concomitant change in mEPSC amplitude (vehicle $-11.3 \pm 0.7 \mathrm{pA}$; EB $-9.4 \pm$ $0.6 \mathrm{pA} ; \mathrm{n}=5-17$; Student's t test, $\mathrm{t}=-1.46563, \mathrm{p}<0.16$ ).

\section{Experiment 1: Estrogenic Modulation of the ORL1}

Receptor-Mediated Activation of Postsynaptic GIRK-1

Channels

To investigate whether estradiol influences the ability of $\mathrm{OFQ} / \mathrm{N}$ to inhibit rat $\mathrm{ARH}$ neurons via activation of GIRK-1 channels, patch-clamp recordings were made in hypothalamic slices using biocytin-filled electrodes. $\mathrm{OFQ} / \mathrm{N}(1 \mu \mathrm{M})$ application produced a significant reduction in the firing frequency (fig. 1a) and a corresponding terval distribution between contiguous action potentials derived from the cell in a under basal conditions and in the presence of OFQ/N. ${ }^{*} \mathrm{p}<0.05$, Kolmogorov-Smirnov. increase in the interspike interval (fig. 1b; KolmogorovSmirnov, $\mathrm{p}<0.0001$, K-S statistic $=7.00036)$ of ARH neurons. In the presence of TTX, OFQ/N $(1 \mu \mathrm{M})$ induced a reversible outward current (fig. 2a, b) in 61 out of $64 \mathrm{ARH}$ neurons that was associated with an increase in slope conductance (fig. 2c, d) and reversed polarity near the Nernst equilibrium potential for $\mathrm{K}^{+}$(fig. 2c). These effects of $\mathrm{OFQ} / \mathrm{N}$ were markedly attenuated in the presence of either the ORL1 receptor antagonist UFP-101 (100 nM; fig. 2a, c, d) or the GIRK channel blocker tertiapin (10 nM; fig. $2 \mathrm{~b}-\mathrm{d} ; \Delta \mathrm{I}$ : multifactorial ANOVA/LSD, $\mathrm{F}_{\text {antagonist }}=$ $8.26, \mathrm{p}<0.0003$, d.f. $=2 ; \mathrm{F}_{\text {voltage }}=5.19, \mathrm{p}<0.0001$, d.f. $=$ $8 ; \mathrm{F}_{\text {interaction }}=3.70, \mathrm{p}<0.0001$, d.f. $=16 ; \Delta \mathrm{g}:$ multifactorial ANOVA, $\mathrm{F}_{\text {antagonist }}=10.79, \mathrm{p}<0.0001$, d.f. $=2$; $\mathrm{F}_{\text {voltage }}=0.47, \mathrm{p}<0.50$, d.f. $=1 ; \mathrm{F}_{\text {interaction }}=0.09, \mathrm{p}<0.92$, d.f. $=2 ; n=3-14)$. Interestingly, we observed that compared to neuronal recordings from vehicle-treated rats, EB significantly reduced the OFQ/N-induced postsynaptic currents without affecting the reversal potential for $\mathrm{K}^{+}$ (fig. 3a-c; $\Delta \mathrm{I}$ : multifactorial ANOVA/LSD, $\mathrm{F}_{\text {steroid }}=0.07$, $\mathrm{p}<0.80$, d.f. $=1 ; \mathrm{F}_{\text {voltage }}=29.69, \mathrm{p}<0.0001$, d.f. $=8$; $\mathrm{F}_{\text {interaction }}=8.75, \mathrm{p}<0.0001$, d.f. $=8 ; \Delta \mathrm{g}:$ multifactorial ANOVA, $\mathrm{F}_{\text {steroid }}=22.73, \mathrm{p}<0.0001$, d.f. $=1 ; \mathrm{F}_{\text {voltage }}=$ $0.85, \mathrm{p}<0.40$, d.f. $=1 ; \mathrm{F}_{\text {interaction }}=0.25, \mathrm{p}<0.62$, d.f. $=1$; $\mathrm{n}=13-19)$.

\section{Experiment 2: Estrogenic Modulation of the ORL1 \\ Receptor-Mediated Presynaptic Inhibition of \\ Glutamatergic Neurotransmission \\ To determine whether estradiol also alters OFQ/N-in-} duced presynaptic inhibition of glutamatergic input onto ARH neurons, we evaluated mEPSC frequency and amplitude in slices collected from EB- and vehicle-treated female rats. In ARH neurons from vehicle-treated animals, OFQ/N $(1 \mu \mathrm{M})$ produced a substantial increase in 


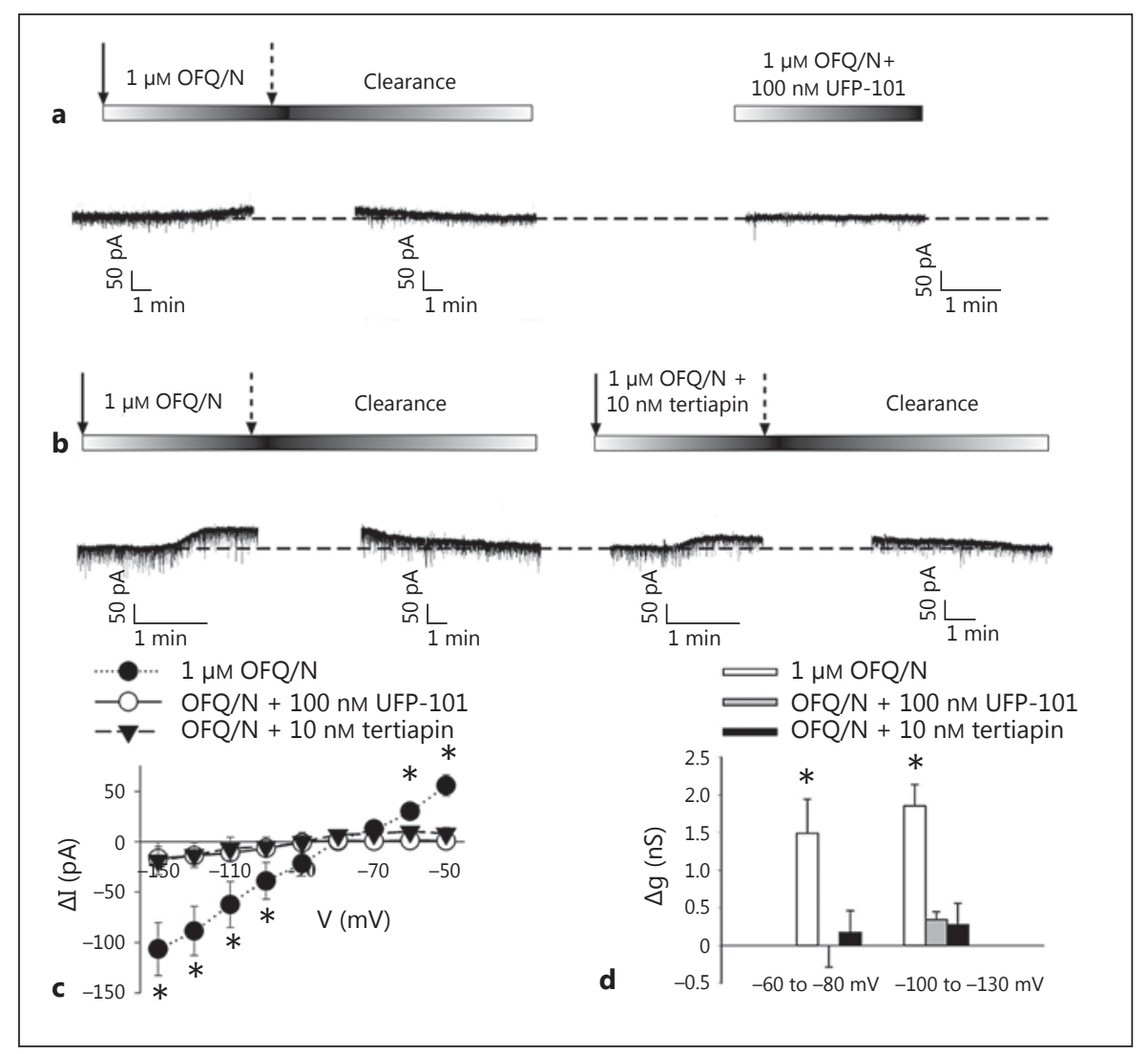

Fig. 2. Postsynaptic OFQ/N-induced membrane currents are reduced by antagonizing either ORL1 or the GIRK-1 channel. a, b Membrane current traces recorded in identified POMC neurons from vehicle-treated OVX animals illustrating the OFQ/N-induced outward current recorded in the presence of $1 \mu \mathrm{M}$ TTX that is attenuated by either the ORL1 antagonist UFP-101 (a)** or the GIRK-1 channel blocker tertiapin (b). The solid arrows represent the beginning of the OFQ/N and TTX application, whereas the broken arrows represent the end of the application. $c$ This I/V plot illustrates the reduced currents induced in the presence of either UFP-101 or tertiapin. d Composite bar graph illustrating the

the interval between contiguous mEPSCs (KolmogorovSmirnov, $\mathrm{p}<0.05$, K-S statistic $=1.2728$; Mann-Whitney $\mathrm{W}$ test, $\mathrm{p}<0.05, \mathrm{~W}$ statistic $=6.0 ; \mathrm{n}=3-4)$, indicating a decrease in $\mathrm{mEPSC}$ frequency. This is exemplified by the representative membrane current traces (fig. 4a) and the cumulative probability plot (fig. $4 \mathrm{~b}$ ) as well as the composite data from these cells (fig. $5 \mathrm{~d}$ ). OFQ/N was without effect on mEPSC amplitude (data not shown). The ability of OFQ/N to decrease mEPSC frequency was blocked by UFP-101 (fig. 5a, c, d; Kolmogorov-Smirnov, p < 0.91, $\mathrm{K}-\mathrm{S}$ statistic $=0.5657$; Mann-Whitney $\mathrm{W}$ test, $\mathrm{p}<0.05$, $\mathrm{W}$ statistic $=6.0 ; \mathrm{n}=3-4)$. Application of the ionotropic glutamate receptor antagonists $\mathrm{NBQX}(3 \mu \mathrm{M})$ and marked reduction in slope conductance $(\Delta \mathrm{g})$ caused by UFP-101 and tertiapin. ${ }^{*} \mathrm{p}<0.05$, multifactorial ANOVA/LSD, $\mathrm{n}=3-16$. ** For a, due to the fact that the onset of the original response was 3 min into the OFQ application, we waited until 2 min after the OFQ + UFP-101 application before beginning the data acquisition (to save bandwidth). Therefore, the end of the trace in the right panel is actually 5 min into the OFQ + UFP-101 application, at which point we see no change in the holding current. Moreover, after the second I/V, we monitored the holding current for an additional $7 \mathrm{~min}$ in the presence of OFQ + UFP-101 before detaching from the cell, and we still did not see any change.

CGS $19755(10 \mu \mathrm{M})$ caused a reversible ablation of these mEPSCs (fig. 5b). Most importantly, the graded OFQ/Ninduced increase in mEPSC interval (and decrease in mEPSC frequency) observed in figures $6 \mathrm{a}$ and 7 [Kolmogorov-Smirnov, $\mathrm{p}<0.02$ (100 nM OFQ) and 0.0003 $(1 \mu \mathrm{M}$ OFQ $)]$, K-S statistics $=1.6211(100 \mathrm{nM} \mathrm{OFQ})$ and $2.12132(1 \mu \mathrm{M}$ OFQ) ] was considerably dampened in ARH neurons from EB-treated animals [fig. 6b, 7; KolmogorovSmirnov, $\mathrm{p}<0.60$ (100 nM OFQ) and 0.25 (1 $\mu \mathrm{M}$ OFQ), K-S statistics $=0.774339(100 \mathrm{nM}$ OFQ $)$ and $1.03257(1 \mu \mathrm{M}$ OFQ), and rank-transformed two-way ANOVA/LSD, $\mathrm{F}_{\text {steroid }}=38.89, \mathrm{p}<0.0002$, d.f. $=1 ; \mathrm{F}_{\text {dose } \mathrm{OFQ} / \mathrm{N}}=3.23, \mathrm{p}<$ 0.11 , d.f. $=1 ; \mathrm{F}_{\text {interaction }}=0.01, \mathrm{p}<0.91$, d.f. $\left.=1 ; \mathrm{n}=3-4\right]$. 
Fig.3. Estradiolattenuates $\mathrm{OFQ} / \mathrm{N}$-induced postsynaptic currents. a Membrane current traces from identified POMC neurons recorded in the presence of $1 \mu \mathrm{M}$ TTX showing that $2 \mu \mathrm{g}$ EB given $30 \mathrm{~h}$ earlier to OVX rats had reduced $\mathrm{OFQ} / \mathrm{N}$-induced outward currents compared to the recorded neurons from vehicle-treated control rats. The solid arrows represent the commencement of the OFQ/N and TTX application, whereas the broken arrows denote the cessation of the application. $\mathbf{b}$ This I/V plotillustrates the reduced $\mathrm{OFQ} / \mathrm{N}$-induced currents in neurons from EB-treated rats compared to oil vehicle controls. c Composite bar graph illustrating the marked reduction in $\Delta \mathrm{g}$ caused by $\mathrm{EB}$ compared to oil vehicle control rats. ${ }^{*} \mathrm{p}<0.05$, multifactorial ANOVA/LSD, $\mathrm{n}=16-19$.

Fig. 4. OFQ/N decreases mEPSC frequency in ARH neurons. a Traces of membrane current in an identified POMC neuron from a vehicle-treated animal recorded under baseline conditions (left) and in the presence of $1 \mu \mathrm{M} \mathrm{OFQ} / \mathrm{N}$ (right). b A quantile plot derived from the cell in a that depicts the distributions of mEPSC interval measured under baseline conditions and in the presence of OFQ/N. ${ }^{*} \mathrm{p}<0.05$, Kolmogorov-Smirnov.
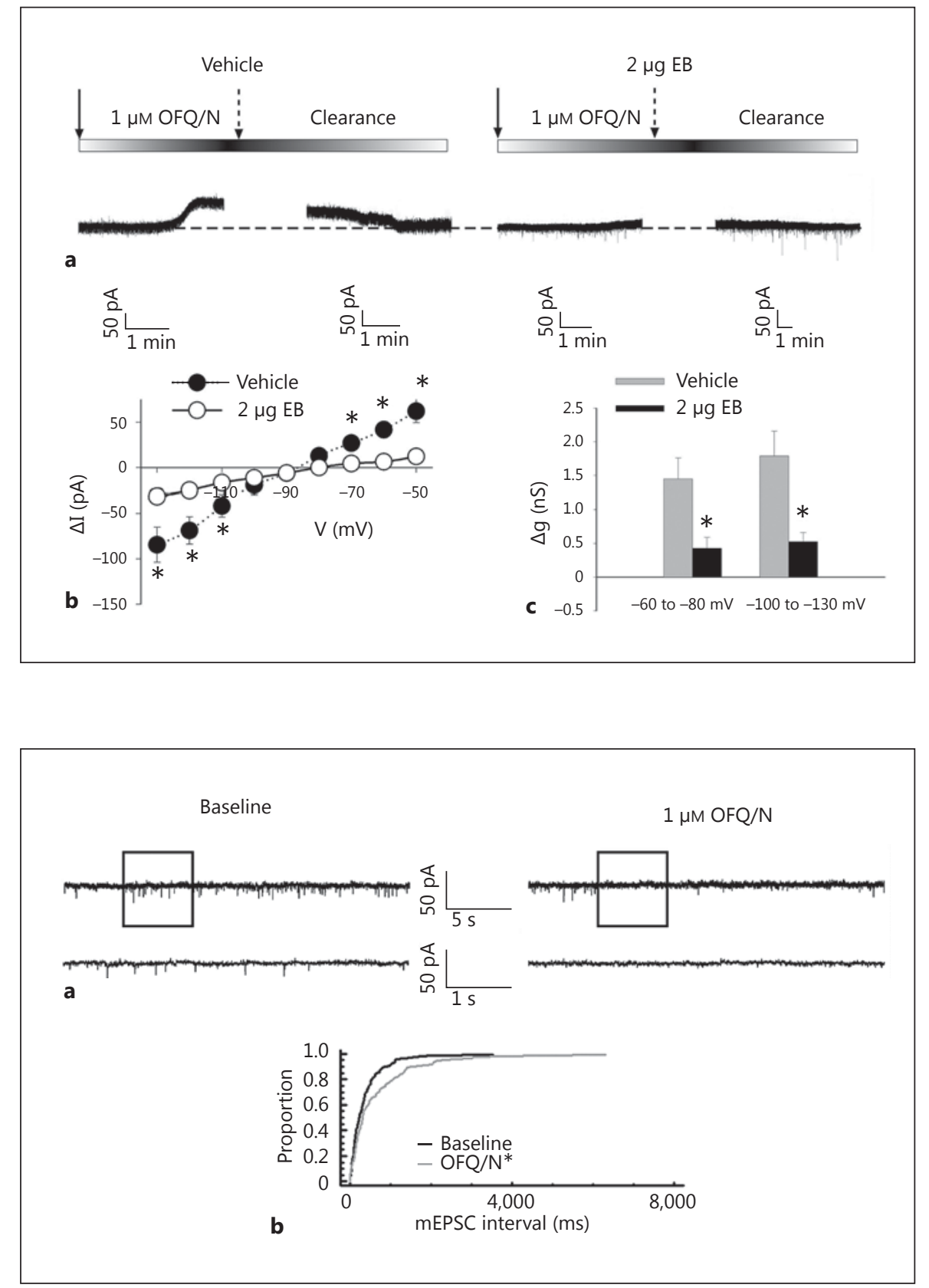

We attempted to identify 30 of the $86 \mathrm{ARH}$ neurons evaluated in the present study after electrophysiological recording. Of these, 20 cells were immunocytochemically identified using phenotypic markers of POMC neurons, whereas 10 cells were immunonegative for these markers. The pleiotropic actions of OFQ/N, and their negative modulation by $\mathrm{EB}$, were observed in these 20 POMC neurons, including eight MPN-projecting POMC neurons that were labeled with Fluorogold in their peri- karya (fig. 8). Table 1 summarizes these effects on POMC neurons and unidentified ARH neurons in slices from vehicle- and EB-treated rats. It is noteworthy that the $\mathrm{OFQ} / \mathrm{N}$-induced outward current and increase in slope conductance are considerably more robust in POMC neurons than in unidentified ARH neurons, whereas the decrease in mEPSC frequency is comparable between the two populations. 
Fig. 5. $O F Q / N$-induced decrease in the frequency of glutamatergic mEPSCs is blocked by the ORL1 receptor antagonist UFP-101. a Traces of membrane current in an identified POMC neuron from a vehicle-treated animal recorded under baseline conditions (left) and in the presence of $1 \mu \mathrm{M}$ OFQ/N and $100 \mathrm{nM}$ UFP-101 (right). b Membrane current traces from the cell in a recorded in the presence of $3 \mu \mathrm{M}$ NBQX and $10 \mu \mathrm{M}$ CGS 19755 showing the reversible inhibition of mEPSCs by these ionotropic glutamate receptor antagonists. c A quantile plot derived from the cell in a that represents the distributions of MEPSC interval measured under baseline conditions and in the presence of OFQ/N and UFP101. d Composite bar graph revealing the blockade of the OFQ/N-induced decrease in mEPSC frequency by UFP-101. * $\mathrm{p}<$ 0.05 , Mann-Whitney W test, $\mathrm{n}=3-4$.

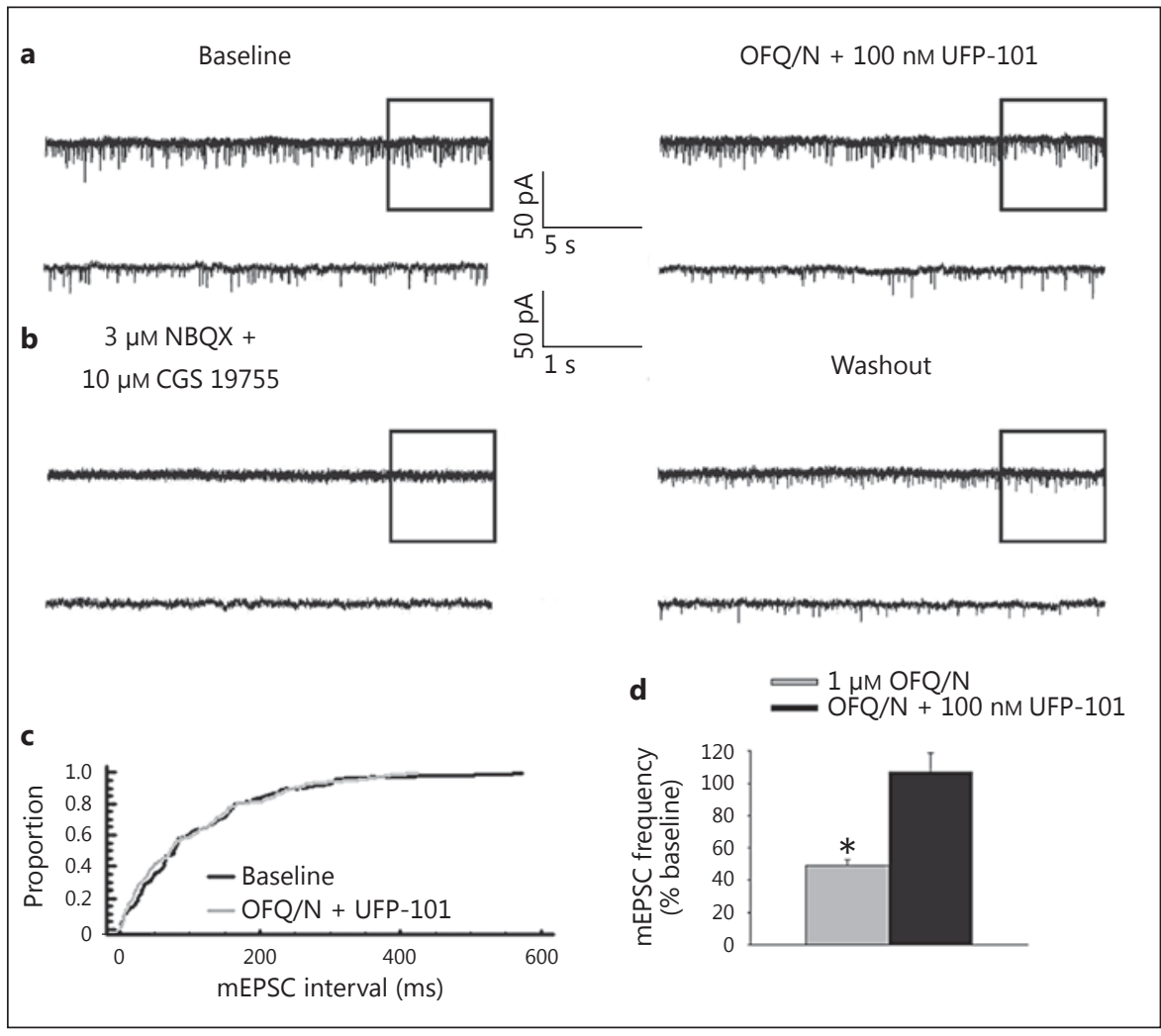

Table 1. Summary of the post- and presynaptic actions of OFQ/N on POMC neurons and unidentified ARH neurons in slices from EBand vehicle-treated animals

\begin{tabular}{lllll}
\hline & $\begin{array}{l}\text { POMC cells, } \\
\text { vehicle-treated }\end{array}$ & $\begin{array}{l}\text { non-POMC cells, } \\
\text { vehicle-treated }\end{array}$ & $\begin{array}{l}\text { POMC cells, } \\
\text { EB-treated }\end{array}$ & $\begin{array}{l}\text { non-POMC cells, } \\
\text { EB-treated }\end{array}$ \\
\hline$\Delta \mathrm{I}(-60 \mathrm{mV} ; \mathrm{pA})$ & $84.9 \pm 11.7^{*}$ & $43.8 \pm 7.5$ & $18.9 \pm 9.7^{*, \#}$ & $10.5 \pm 5.5^{\#}$ \\
$\Delta \mathrm{g}(-60$ to $-80 \mathrm{mV} ; \mathrm{nS})$ & $2.72 \pm 0.42^{*}$ & $0.86 \pm 0.19$ & $0.29 \pm 0.25^{\#}$ & $0.46 \pm 0.20$ \\
$\Delta \mathrm{g}(-100$ to $-130 \mathrm{mV} ; \mathrm{nS})$ & $2.48 \pm 0.26^{*}$ & $1.33 \pm 0.23$ & $0.71 \pm 0.30^{*}, \#$ & $0.21 \pm 0.19^{\#}$ \\
mEPSC frequency $(\%$ baseline $)$ & $54.1 \pm 5.9$ & $54.9 \pm 9.2$ & $95.6 \pm 2.5^{\#}$ & $95.7 \pm 3.4^{\#}$ \\
\hline
\end{tabular}

The postsynaptic activation of GIRK-1 channels was assessed by measuring the change in the membrane holding current $(\Delta \mathrm{I})$ at -60 $\mathrm{mV}$, and the change in slope conductance $(\Delta \mathrm{g})$ measured at -60 to $-80 \mathrm{mV}$ and -100 to $-130 \mathrm{mV}$, in the presence of $1 \mu \mathrm{M} \mathrm{OFQ} / \mathrm{N}$. The presynaptic inhibition of glutamate release was evaluated by examining the change in mEPSC frequency in the presence of $100 \mathrm{~nm}$ OFQ/N. * Values from POMC neurons that are significantly different $(\mathrm{p}<0.05$, two-way ANOVA/LSD, $\mathrm{n}=3-22)$ from those from unidentified ARH neurons. * Values in neurons from EB-treated animals that are significantly different ( $p<0.05$, two-way ANOVA/ LSD, $\mathrm{n}=3-22$ ) from those from their vehicle-treated counterparts.

\section{Discussion}

The results of the present study demonstrate that the in vivo administration of estradiol $30 \mathrm{~h}$ prior to experimentation negatively modulates the postsynaptic inhibitory effects of ORL1 activation on POMC neurons that project to the MPN, as well as the presynaptic inhibition of glutamatergic excitatory input impinging upon them. This conclusion is based on the following observations: (1) OFQ/N elicited a robust outward current in identified, Fluorogold-filled POMC neurons from OVX, vehicle-treated animals that was blocked by 


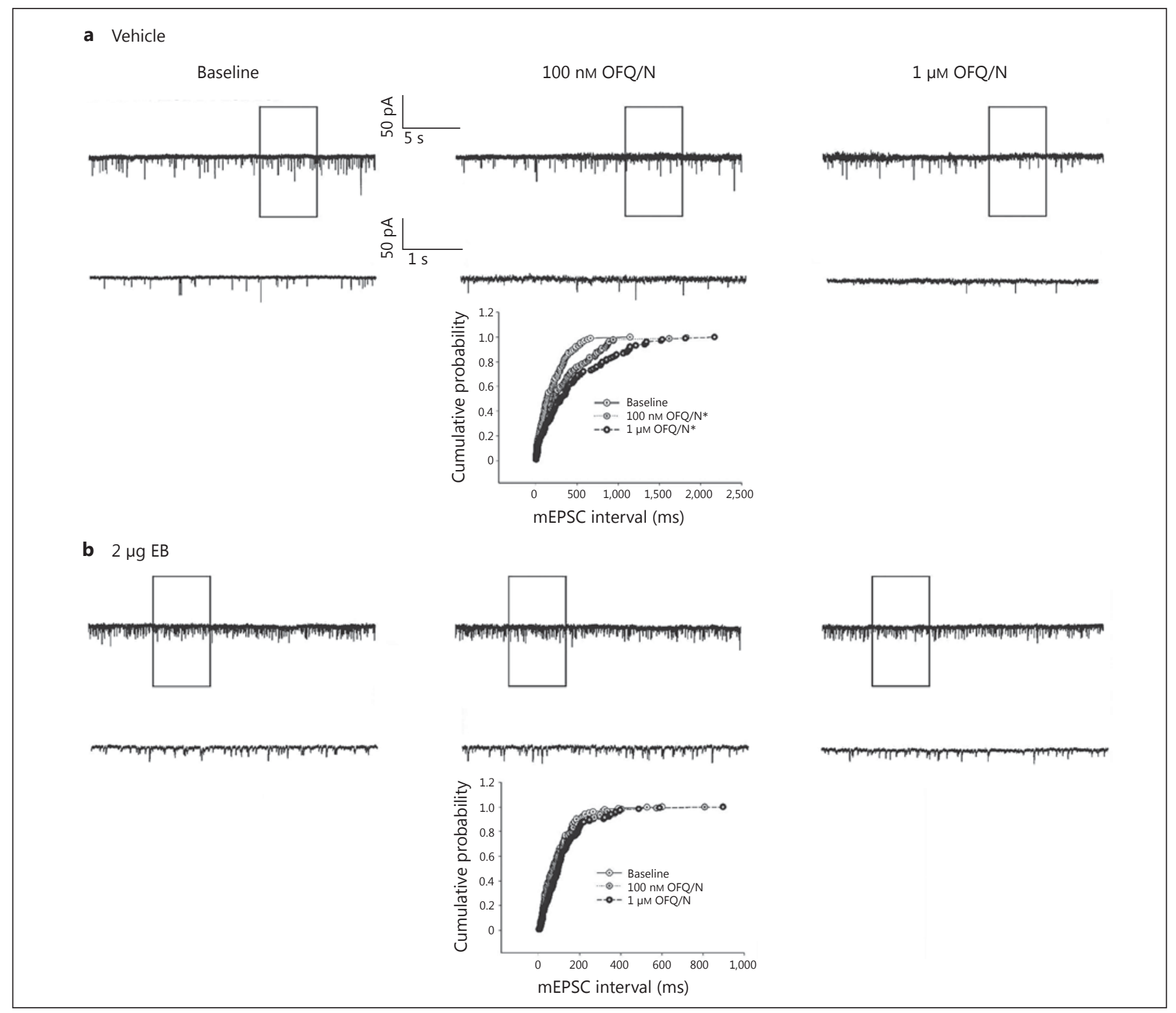

Fig. 6. Estradiol $(2 \mu \mathrm{g})$ attenuates the decrease in mEPSC frequency caused by $\mathrm{OFQ} / \mathrm{N}$. Membrane current traces and cumulative probability distributions derived from identified POMC neurons showing the dose-dependent OFQ/N-induced decrease in mEPSC

the ORL1 receptor antagonist, UFP-101 and the GIRK channel blocker tertiapin, and markedly attenuated in POMC neurons from EB-treated animals; (2) OFQ/N decreased the frequency of mEPSCs in POMC neurons from vehicle-treated animals that were abolished by ionotropic glutamate receptor antagonists, and (3) this $\mathrm{OFQ} / \mathrm{N}$-induced decrease in glutamate release at POMC synapses was blocked by UFP-101, and significantly reduced in EB-treated animals.

Estrogens and Pleiotropic ORL1 Receptor Signaling frequency in a recording from an oil vehicle-treated OVX rat (a), and the estradiol diminution of the $\mathrm{OFQ} / \mathrm{N}$-induced decrease in mEPSC frequency in a recording from an OVX rat primed with EB $30 \mathrm{~h}$ earlier $(\mathbf{b}) .{ }^{*} \mathrm{p}<0.05$, Kolmogorov-Smirnov.

The ORL1 receptor-mediated activation of GIRK that we observed in the present study is consistent with that described elsewhere in the central nervous system including, but not limited to, the locus coeruleus [4], the periaqueductal gray [5], the nucleus raphe magnus [6], the tuberomammillary nucleus [10], the SCN [9], the VMN $[7,8]$ and the ARH $[7,11,12]$. This ORL1 receptor-mediated activation of GIRK-1 channels presently seen in the overwhelming majority of rat ARH neurons is virtu- 


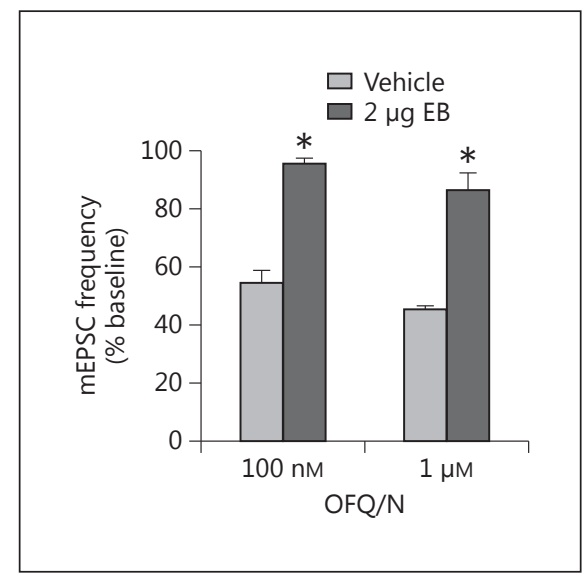

Fig. 7. Composite bar graph that illustrates the estrogenic attenuation of the OFQ/N-induced decrease in mEPSC frequency. Bars represent means and vertical lines 1 SEM of the mEPSC frequency that was normalized to values observed under baseline conditions. $* \mathrm{p}<0.05$, rank-transformed two-way ANOVA/LSD, $\mathrm{n}=3-4$.

ally indistinguishable from that reported for guinea pigs and mice. In the guinea pig, the OFQ/N-induced hyperpolarization and outward current encountered in POMC neurons was blocked by $\mathrm{Ba}^{2+}[11]$, whereas in the mouse [12] and presently in the rat it is antagonized by tertiapin. While it is true that tertiapin did not completely block the $\mathrm{OFQ} / \mathrm{N}$-induced activation of GIRK-1 channels, it is clear from looking at figure $1 \mathrm{in}$ its totality that it did markedly attenuate the response. This observation points to the critical role that GIRK-1 channels play in inhibiting POMC neurons. Perhaps a higher dose would have fully antagonized the response. Alternatively, $\mathrm{OFQ} / \mathrm{N}$ can also inhibit an array of voltage-gated $\mathrm{Ca}^{2+}$ channels [13-15]. Perhaps the OFQ/N-induced inhibition of these voltagegated $\mathrm{Ca}^{2+}$ channels and/or activation of (an)other type(s) of $\mathrm{K}^{+}$channel(s) (e.g. KATP channels) contribute to the $\mathrm{OFQ} / \mathrm{N}$-induced decrease in neuronal excitability. In addition, the profound inhibition of the GIRK currents caused by UFP-101 is comparable to that seen in ORL1 receptor knockout mice [12]. Likewise, the ORL1 receptor-mediated decrease in the frequency of mEPSCs impinging upon POMC neurons is in agreement with that described in the SCN [15], the lateral amygdala [16] and the ARH [12]. Moreover, the lack of effect at rat POMC synapses seen presently following co-treatment with UFP-101 is nearly identical to that reported in ORL1 receptor knockout mice [12]. These latter two findings, coupled with the fact that we and others have shown that $\mathrm{OFQ} / \mathrm{N}$ decreases presynaptic $\mathrm{Ca}^{2+}$ concentrations, re-

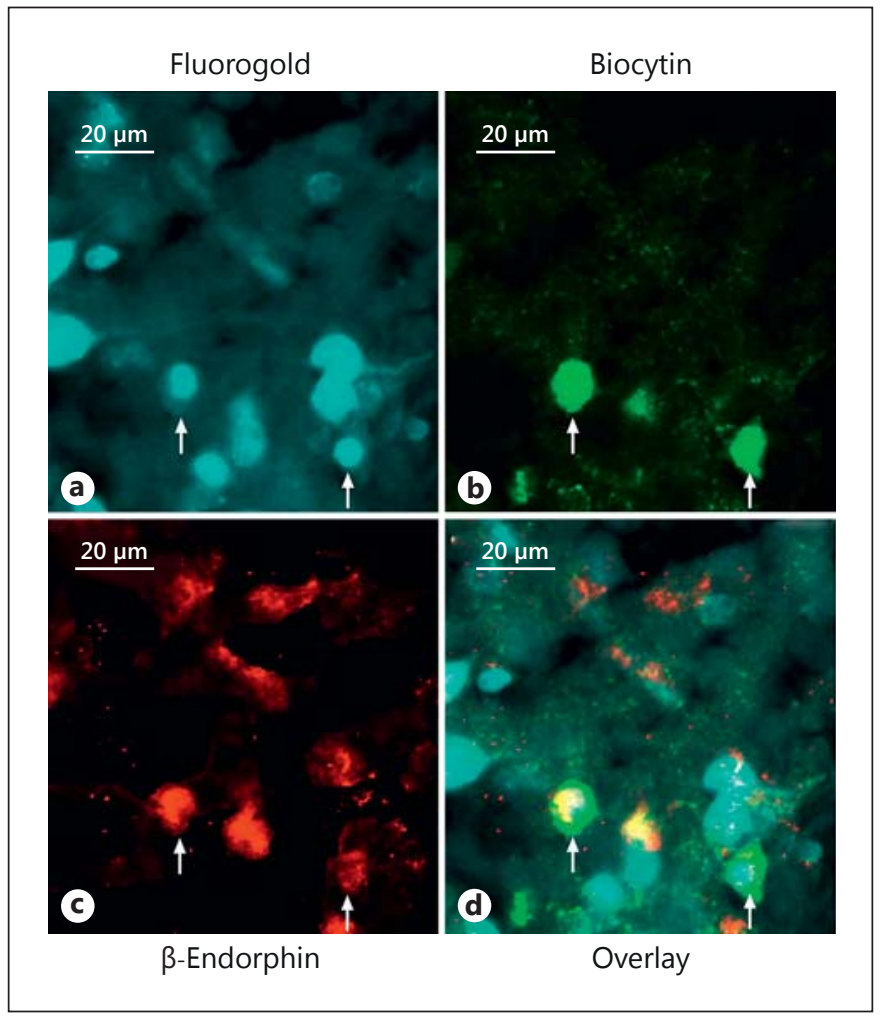

Fig. 8. Color photomicrograph of MPN-projecting ARH POMC neurons from which electrophysiological recordings are taken. a Retrogradely labeled neurons in the ARH filled with Fluorogold that was injected into the MPN. b Biocytin labeling of presumably coupled neurons filled throughout a long ( $>45 \mathrm{~min}$ ), stable (unwavering series resistance) recording and visualized with AF488. c Neuronal somata and fibers that are immunopositive for $\beta$-endorphin as visualized by AF546. d Merged photomicrographs from a-c illustrating the ARH neurons (denoted by the arrows) that were triple labeled with Fluorogold, biocytin and POMC immunoreactivity.

duces evoked EPSC amplitude and increases the S2/S1 ratio, is indicative of a presynaptic effect due likely to an ORL1 receptor-mediated attenuation of $\mathrm{Ca}^{2+}$ influx through voltage-gated channels $[7,12,15,16]$. Arguably the principal function of the GIRK-1 channel is to produce a hyperpolarization of the plasma membrane that decreases the likelihood that the threshold for the activation of voltage-gated $\mathrm{Na}^{+}$channels will be reached, thereby decreasing the firing rate or causing a cessation of action potential firing altogether [38]. Likewise, the spontaneous EPSCs caused by the activation of ionotropic glutamate receptors brings the membrane potential closer to the threshold for the activation of voltage-gated $\mathrm{Na}^{+}$ channels, thereby increasing the probability that an ac- 
tion potential will be generated [39-42]. Thus, this pleiotropic activation of postsynaptic GIRK channels in POMC neurons, concomitant with decreased glutamate release from upstream nerve terminals, undoubtedly leads to a powerful inhibition of POMC excitability.

Of course, the estrogenic uncoupling of ORL1 receptors from their effector systems would increase the excitability of POMC neurons. First, we show that estradiol diminishes ORL1 receptor-mediated activation of postsynaptic GIRK channels in POMC neurons, which would reduce outward $\mathrm{K}^{+}$currents that could hyperpolarize and thereby decrease the firing rate of POMC neurons. This is congruent with previously documented accounts of estradiol-induced uncoupling of $\mu$-opioid and $\mathrm{GABA}_{\mathrm{B}}$ receptors from their GIRK channels in POMC neurons, which can be attributed to the activation of a phosphatidylinositol-3-kinase (PI3K)/phospholipase C/protein kinase $\mathrm{C}(\mathrm{PKC}) /$ protein kinase A (PKA) pathway [30, 43, 44]. We also observed that estradiol per se increased the glutamatergic synaptic input onto POMC neurons. This is consistent with the fact that (1) estrogen receptors colocalize with AMPA receptor GluR1 subunits in over $50 \%$ of ARH neurons [45]; (2) estradiol increases asymmetric synapse formation in the ARH [46] and in cultured hippocampal neurons [47]; (3) estradiol increases AMPA receptor subunit expression in the hypothalamus [45]; (4) estradiol stimulates dendritic spine formation in the $\mathrm{VMN}$, the ARH and the hippocampus by mechanisms that appear to involve PI3K, metabotropic glutamate receptor signaling and a reduction in inhibitory GABAergic neurotransmission [48-50], and (5) estradiol presynaptically facilitates glutamate release in developing hypothalamic neurons via the activation of PI3K [49]. Estradiol also acts through estrogen receptor (ER) $\alpha$ and ER $\beta$ in the hippocampus, and ERa in the hypothalamus, to enhance metabotropic glutamate receptor signaling $[49,51]$. Lastly, we found that estradiol suppressed the ORL1 receptormediated presynaptic inhibition of glutamatergic input, which is in keeping with the fact that the steroid activates $\mathrm{ER} \alpha$ and the $\mathrm{G}_{\mathrm{q}}$-coupled membrane ER to diminish CB1 receptor-mediated inhibition of glutamate release at POMC synapses via PI3K, PKC $\delta$ and, to a lesser extent, PKA $[52,53]$. Coupled with considerable precedence for estradiol-induced changes in $\mathrm{Ca}^{2+}$ flux and mobilization in hypothalamic neurons and glia [54-56], it is certainly possible that the steroid is interfering with the mechanism through which presynaptic ORL1 receptors decrease $\mathrm{Ca}^{2+}$ influx into the nerve terminal. Given that estradiol is functionally disengaging the ORL1 receptor from the effector systems that hyperpolarize POMC neu-

Estrogens and Pleiotropic ORL1 Receptor Signaling rons and decrease glutamatergic input impinging upon these cells, we interpret this by concluding that the steroid lessens the hyperpolarization and lessens the inhibition of glutamatergic input, thereby increasing the excitability of POMC neurons. The ability of estradiol to diminish the $\mu$-opioid and $\mathrm{GABA}_{B}$ receptor-mediated activation of GIRK channels in, as well as the CB1 receptor-mediated decrease in glutamate release onto, POMC neurons is both rapid (i.e. it is initially observed within minutes following bath application $[29,32,30,43,44])$ and sustained (i.e. it continues to be seen at least $24 \mathrm{~h}$ following systemic administration $[28,33])$. These findings make for a compelling hypothesis that estradiol acts rapidly to uncouple the ORL1 receptor from its effector systems, and this will be tested in future experiments.

Thus, our current findings indicate that estradiol enhances the activity of the POMC neurons that project to the MPN, at least in part, by diminishing postsynaptic activation of GIRK-1 channels and the presynaptic inhibition of glutamate release. It follows logically that the estradiol-induced disruption of the pleiotropic signaling of $\mathrm{G}_{\mathrm{i} / \mathrm{o}}$-coupled receptors like the ORL1 receptor would serve to increase the release of posttranslational by-products of POMC processing like $\beta$-endorphin. Indeed, estradiol increases the release of $\beta$-endorphin measured in hypophysial portal blood during the mid-follicular phase of the primate ovarian cycle [24], and increases $\beta$-endorphin expression [25] and release [24] in OVX rodents and primates, respectively. The increased $\beta$-endorphin release would stimulate $\mu$-opioid receptors in the MPN which receives the terminal fields of rostrally projecting POMC neurons, leading to their internalization [22, 57]. This activation of POMC neurons occurring prior to ovulation is essential for subsequent female sexual behavior, as pretreatment with the opioid receptor antagonist naltrexone not only blocked the $\mu$-opioid receptor internalization but also compromised sexual receptivity in rats to a degree similar to that observed in $\mu$-opioid receptor knockout mice $[22,58,59]$.

The ability of estradiol to interfere with ORL1 signaling at POMC synapses extends beyond reproductive behavior. ORL1 receptor activation elicits appreciable effects on energy homeostasis. Centrally administered $\mathrm{OFQ} / \mathrm{N}$ increases food intake and adiposity, and decreases core body temperature and uncoupling protein-1 expression in brown adipose tissue [60-62]. The hyperphagic effect of $\mathrm{OFQ} / \mathrm{N}$ is reportedly blocked by the $\mathrm{N}$-terminal tridecapeptide analog $\left[\mathrm{Nphe}^{1}\right] \mathrm{OFQ} / \mathrm{N}(1-13) \mathrm{NH}_{2}$, by antisense probes directed against the ORL1 receptor, by genetic ORL1 receptor ablation and by comparatively 
high doses of naloxone or naltrexone [12, 60, 61, 63]. In addition, OFQ/N decreases c-Fos activation in anorexigenic POMC neurons involved in meal termination [64]. This estrogenic diminution of pre- and postsynaptic ORL1 receptor-mediated signaling may very well contribute to the decrease in energy intake caused by the steroid in both humans and rodent animal models [65-68].

The multifaceted effects of ORL1 receptor activation observed in the present study inhibited a high percentage of identified POMC neurons (20 immunopositive cells out of 30 tested), many of which also projected to the MPN. It is highly unlikely, however, that other neuronal populations in the ARH were unaffected. Indeed, $\mathrm{OFQ} / \mathrm{N}$ also hyperpolarizes $\mathrm{A}_{12}$ dopamine and gonadotropin-releasing hormone neurons in the guinea pig ARH [11]. $\mathrm{A}_{12}$ dopamine neurons tonically inhibit prolactin secretion from the anterior pituitary [69], and so therefore OFQ/N-induced decreases in the neuronal activity of these cells are associated with increases in circulating prolactin concentrations [70]. Given the well-known fact that estradiol increases the excitability of $\mathrm{A}_{12}$ dopamine neurons [69], it is quite plausible that the decreased ORL1 receptor-mediated signaling observed presently contributes to the activation of these cells. Likewise, the OFQ/N-induced inhibition of GnRH neurons is consistent with decreased $\mathrm{GnRH}$ release in medial preoptic and mediobasal hypothalamic slices, as well as decreased circulating levels of luteinizing hormone, from OVX rats [71]. OFQ/N also diminishes the magnitude of the luteinizing hormone surge seen in estradiol-primed, progesterone-treated rats. Moreover, OFQ/N expression in the ARH is decreased during proestrus [72], at a time when estradiol levels are at their highest, which parallels the estrogenic disruption in ORL1 receptor-mediated signaling that we observed in the present study.

In conclusion, the results of the present study demonstrate that estradiol negatively modulates the inhibitory, pre- and postsynaptic actions of OFQ/N on ARH POMC neurons that project to the MPN and are involved in female sexual receptivity. These data provide insight and a newfound appreciation for how estradiol attenuates the signaling imparted by $\mathrm{G}_{\mathrm{i} / \mathrm{o}}$-coupled receptors to activate these POMC neurons that are important for reproduction and possibly energy balance.

\section{Acknowledgements}

The authors thank Cecilia Meza for her technical assistance. This study was supported by PHS Grants HD058638 and DA024314.

\section{References}

1 Bunzow JR, Saez C, Mortrud M, Bouvier C, Williams JT, Low M, Grandy DK: Molecular cloning and tissue distribution of a putative member of the rat opioid receptor gene family that is not a $\mu, \delta$ or $\kappa$ opioid receptor type. FEBS Lett 1994;347:284-288.

-2 Reinscheid RK, Nothacker H-P, Bourson A, Ardati A, Henningsen RA, Bunzow JR, Grandy DK, Langen H, Monsma FJ, Civelli O: Orphanin FQ: a neuropeptide that activates an opioid-like G protein-coupled receptor. Science 1995;270:792-794.

$>3$ Meunier J-C, Mollereau C, Toll L, Suaudeau C, Moisand C, Alvinerie P, Butour J-L, Guillemot J-C, Ferrara P, Monsarrat B, Mazarguil H, Vassart G, Permentier M, Constentin J: Isolation and structure of the endogenous agonist of opioid receptor-like $\mathrm{ORL}_{1}$ receptor. Nature 1995;377:532-535.

4 Connor M, Vaughan CW, Chieng B, Christie MJ: Nociceptin receptor coupling to a potassium conductance in rat locus coeruleus neurones in vitro. Br J Pharmacol 1996;119:16141618.
Vaughan CW, Ingram SL, Christie MJ: Actions of the $\mathrm{ORL}_{1}$ receptor ligand nociceptin on membrane properties of rat periaqueductal gray neurons in vitro. J Neurosci 1997;17: 996-1003.

-6 Pan ZZ, Hirakawa N, Fields HL: A cellular mechanism for the bidirectional pain-modulating actions of orphanin FQ/nociceptin. Neuron 2000;26:515-522.

7 Emmerson PJ, Miller RJ: Pre- and postsynaptic actions of opioid and orphan opioid agonists in the rat arcuate nucleus and ventromedial hypothalamus in vitro. J Physiol (Lond) 1999;517:431-445.

-8 Chee MJ, Price CJ, Statnick MA, Colmers WF: Nociceptin/orphanin FQ suppresses the excitability of neurons in the ventromedial nucleus of the hypothalamus. J Physiol (Lond) 2011;589:3103-3114.

$\checkmark 9$ Allen CN, Jiang Z-G, Teshima K, Darland T, Ikeda M, Nelson CS, Quigley DI, Yoshioka T, Allen RG, Rea MA, Grandy DK: OrphaninFQ/Nociceptin (OFQ/N) modulates the activity of suprachiasmatic nucleus neurons. J Neurosci 1999; 19:2152-2160.
0 Bajic D, Hoang QV, Nakajima S, Nakajima Y: Dissociated histaminergic neuron cultures from the tuberomammillary nucleus of rats: culture methods and ghrelin effects. J Neurosci Methods 2004;132:177-184.

-11 Wagner EJ, Rønnekleiv OK, Grandy DK, Kelly MJ: The peptide orphanin FQ inhibits $\beta$-endorphin neurons and neurosecretory cells in the hypothalamic arcuate nucleus by activating an inwardly-rectifying $\mathrm{K}^{+}$conductance. Neuroendocrinology 1998;67:73-82.

$>12$ Farhang B, Pietruszewski L, Lutfy K, Wagner EJ: The role of the NOP receptor in regulating food intake, meal pattern, and the excitability of proopiomelanocortin neurons. Neuropharmacology 2010;59:190-200.

13 Knoflach F, Reinscheid RK, Civelli O, Kemp JA: Modulation of voltage-gated calcium channels by orphanin FQ in freshly dissociated hippocampal neurons. J Neurosci 1996; 16:6657-6664.

14 Abdulla FA, Smith PA: Nociceptin inhibits Ttype $\mathrm{Ca}^{2+}$ channel current in rat sensory neurons by a G-protein-independent mechanism. J Neurosci 1997;17:8721-8728. 
$>15$ Gompf HS, Moldavan MG, Irwin RP, Allen $\mathrm{CN}$ : Nociceptin/orphanin FQ (N/OFQ) inhibits excitatory and inhibitory synaptic signaling in the suprachiasmatic nucleus. Neuroscience 2005;132:955-965.

16 Meis S, Pape H-C: Control of glutamate and GABA release by nociceptin/orphanin FQ in the rat lateral amygdala. J Physiol (Lond) 2001;532:701-712.

-17 Sim LJ, Xiao RY, Childers SR: Identification of opioid receptor-like (ORL1) peptide-stimulated $\left[{ }^{35} \mathrm{~S}\right] \mathrm{GTP} \gamma \mathrm{S}$ binding in rat brain. Neuroreport 1996;7:729-733.

18 Sinchak K, Romeo HE, Micevych PE: Sitespecific estrogen and progestin regulation of orphanin FQ/nociceptin and nociceptin opioid receptor mRNA expression in the female rat limbic hypothalamic system. J Comp Neurol 2006;496:252-268.

19 Olszewski PK, Levine AS: Minireview: characterization of influence of central nociceptin/orphanin FQ on consummatory behavior. Endocrinology 2004;145:2627-2632.

-20 Sinchak K, Dewing P, Cook M, Micevych PE: Release of orphanin FQ/nociceptin in the medial preoptic nucleus and ventromedial nucleus of the hypothalamus facilitates lordosis. Horm Behav 2007;51:406-412.

-21 Sanathara NM, Moraes J, Kanjiya S, Sinchak $\mathrm{K}$ : Orphanin FQ in the mediobasal hypothalamus facilitates sexual receptivity through the deactivation of medial preoptic $\mu$-opioid receptors. Horm Behav 2011;60:540-548.

-22 Eckersell CB, Popper P, Micevych PE: Estrogen-induced alteration of $\mu$-opioid receptor immunoreactivity in the medial preoptic nucleus and medial amygdala. J Neurosci 1998; 18:3967-3976.

-23 Sinchak K, Micevych PE: Progesterone blockade of estrogen activation of $\mu$-opioid receptors regulates reproductive behavior. J Neurosci 2001;21:5723-5729.

24 Ferin M, Van Vugt D, Wardlaw S: The hypothalamic control of the menstrual cycle and the role of endogenous opioid peptides. Recent Prog Horm Res 1984;40:441-485.

25 Thornton JE, Loose MD, Kelly MJ, Rønnekleiv OK: Effects of estrogen on the number of neurons expressing $\beta$-endorphin in the medial basal hypothalamus of the female guinea pig. J Comp Neurol 1994;341:68-77.

26 Mills RH, Sohn RK, Micevych PE: Estrogeninduced $\mu$-opioid receptor internalization in the medial preoptic nucleus is mediated via neuropeptide $\mathrm{Y}-\mathrm{Y} 1$ receptor activation in the arcuate nucleus of female rats. J Neurosci 2004;24:947-955.

27 Dewing P, Christensen A, Bondar G, Micevych $\mathrm{PE}$ : Protein kinase $\mathrm{C}$ signaling in the hypothalamic arcuate nucleus regulates sexual receptivity in female rats. Endocrinology 2008;149:5934-5942.

$\checkmark 28$ Kelly MJ, Loose MD, Rønnekleiv OK: Estrogen suppresses $\mu$-opioid- and $\mathrm{GABA}_{\mathrm{B}}$-mediated hyperpolarization of hypothalamic arcuate neurons. J Neurosci 1992;12:2745-2750.
29 Lagrange AH, Rønnekleiv OK, Kelly MJ: The potency of $\mu$-opioid hyperpolarization of hypothalamic arcuate neurons is rapidly attenuated by $17 \beta$-estradiol. J Neurosci $1994 ; 14$ : 6196-6204.

30 Qiu J, Bosch MA, Tobias SC, Grandy DK, Scanlan TS, Rønnekleiv OK, Kelly MJ: Rapid signaling of estrogen in hypothalamic neurons involves a novel G-protein-coupled estrogen receptor that activates protein kinase C. J Neurosci 2003;23:9529-9540.

31 Tang SL, Tran V, Wagner EJ: Sex differences in the cannabinoid modulation of an A-type $\mathrm{K}^{+}$current in neurons of the mammalian hypothalamus. J Neurophysiol 2005;94:29832986.

32 Kellert BA, Nguyen MC, Nguyen C, Nguyen QH, Wagner EJ: Estrogen rapidly attenuates cannabinoid-induced changes in energy homeostasis. Eur J Pharmacol 2009;622:15-24.

33 Nguyen QH, Wagner EJ: Estrogen differentially modulates the cannabinoid-induced presynaptic inhibition of amino acid neurotransmission in proopiomelanocortin neurons of the arcuate nucleus. Neuroendocrinology 2006;84:123-137.

- 34 Priest CA, Vink KL, Micevych PE: Temporal regulation by estrogen of $\beta$-preprotachykinin mRNA expression in the rat ventromedial nucleus of the hypothalamus. Mol Brain Res 1995;28:61-71.

35 Asarian L, Geary N: Cyclic estradiol treatment normalizes body weight and restores physiologic patterns of spontaneous feeding and sexual receptivity in ovariectomized rats. Horm Behav 2002;42:461-471.

36 Geary N, Asarian L: Cyclic estradiol treatment normalizes body weight and test meal size in ovariectomized rats. Physiol Behav 1999;67:141-147.

37 Ho J, Cox JM, Wagner EJ: Cannabinoid-induced hyperphagia: correlation with inhibition of proopiomelanocortin neurons? Physiol Behav 2007;92:507-519.

38 Rudy B: Diversity and ubiquity of K channels. Neuroscience 1988;25:729-749.

39 Curtis DR, Phillis JW, Watkins JC: Actions of amino-acids on the isolated hemisected spinal cord of the toad. Br J Pharmacol 1961;16:262283.

40 Curtis DR, Watkins JC: Acidic amino acids with strong excitatory actions on mammalian neurones. J Physiol (Lond) 1963;166:1-14.

$41 \mathrm{Hu}$ B, Bourque CW: NMDA receptor-mediated rhythmic bursting activity in rat supraoptic nucleus neurones in vitro. J Physiol (Lond) 1992;458:667-687.

42 Kuehl-Kovarik MC, Pouliot WA, Halterman GL, Handa RJ, Dudek FE, Partin KM: Episodic bursting activity and response to excitatory amino acids in acutely dissociated gonadotropin-releasing hormone neurons genetically targeted with green fluorescent protein. J Neurosci 2002;22:2313-2322.
43 Lagrange AH, Rønnekleiv OK, Kelly MJ: Modulation of $\mathrm{G}$ protein-coupled receptors by an estrogen receptor that activates protein kinase A. Mol Pharmacol 1997;51:605-612.

44 Malyala A, Zhang C, Bryant DN, Kelly MJ, Rønnekleiv OK: PI3K signaling effects in hypothalamic neurons mediated by estrogen. J Comp Neurol 2008;506:895-911.

45 Diano S, Naftolin F, Horvath TL: Gonadal steroids target AMPA glutamate receptor-containing neurons in the rat hypothalamus, septum and amygdala: a morphological and biochemical study. Endocrinology 1997;138: 778-789.

46 Gao Q, Mezei G, Nie Y, Rao Y, Choi CS, Bechmann I, Leranth C, Toran-Allerand D, Priest CA, Roberts JL, Gao X-B, Mobbs C, Shulman GI, Diano S, Horvath TL: Anorectic estrogen mimics leptin's effect on the rewiring of melanocortin cells and Stat 3 signaling in obese animals. Nat Med 2007;13:89-94.

47 Jelks KB, Wylie R, Floyd CL, McAllister AK, Wise P: Estradiol targets synaptic proteins to induce glutamatergic synapse formation in cultured hippocampal neurons: critical role of estrogen receptor-a. J Neurosci 2007;27: 6903-6913.

48 Murphy DD, Cole NB, Greenberger V, Segal M: Estradiol increases dendritic spine density by reducing GABA neurotransmission in hippocampal neurons. J Neurosci 1998;18:25502559.

49 Schwarz JM, Liang S-L, Thompson SM, McCarthy MM: Estradiol induces dendritic spines by enhancing glutamate release independent of transcription: a mechanism for organizational sex differences. Neuron 2008;58: 584-598.

50 Christensen A, Dewing P, Micevych PE: Membrane-initiated estradiol signaling induces spinogenesis required for female sexual receptivity. J Neurosci 2011;31:17583-17589.

51 Boulware MI, Weick JP, Becklund BR, Kuo SP, Groth RD, Mermelstein PG: Estradiol activates group I and II metabotropic glutamate receptor signaling, leading to opposing influences on cAMP response element-binding protein. J Neurosci 2005;25:5066-5078.

52 Jeffery GS, Peng KC, Wagner EJ: The role of phosphatidylinositol-3-kinase and AMP-activated kinase in the rapid estrogenic attenuation of cannabinoid-induced changes in energy homeostasis. Pharmaceuticals 2011;4: 630-651.

53 Washburn N, Borgquist A, Wang K, Jeffery GS, Kelly MJ, Wagner EJ: Receptor subtypes and signal transduction mechanisms contributing to the estrogenic attenuation of cannabinoid-induced changes in energy homeostasis. Neuroendocrinology 2013;97:160-175.

54 Dayanithi G, Tapia-Arancibia L: Rise in intracellular calcium via a nongenomic effect of allopregnanolone in fetal rat hypothalamic neurons. J Neurosci 1996;16:130-136. 
55 Qiu J, Bosch MA, Jamali K, Xue C, Kelly MJ, Rønnekleiv OK: Estrogen upregulates T-type calcium channels in the hypothalamus and pituitary. J Neurosci 2006;26:11072-11082.

56 Kuo J, Hamid N, Bondar G, Prossnitz ER, Micevych PE: Membrane estrogen receptors stimulate intracellular calcium release and progesterone synthesis in hypothalamic astrocytes. J Neurosci 2010;30:12950-12957.

57 Cheung S, Hammer RP: Gonadal steroid hormone regulation of proopiomelanocortin gene expression in arcuate neurons that innervate the medial preoptic area of the rat. Neuroendocrinology 1995;62:283-292.

58 Torii M, Kubo K, Sasaki T: Naloxone and initial estrogen action to induce lordosis in ovariectomized rats: the effect of a cut between the septum and preoptic area. Neurosci Lett 1995;195:167-170.

59 Sinchak K, Shahedi K, Dewing P, Micevych PE: Sexual receptivity is reduced in the female $\mu$-opioid receptor knockout mouse. Neuroreport 2005; 16:1697-1700.

-60 Pomonis JD, Billington CJ, Levine AS: Orphanin FQ, agonist of the orphan opioid receptor, stimulates feeding in rats. Neuroreport 1996;8:369-371.
61 Polidori C, Calò G, Ciccocioppo R, Guerrini R, Regoli D, Massi M: Pharmacological characterization of the nociceptin mediating hyperphagia: identification of a selective antagonist. Psychopharmacology (Berl) 2000;148: 430-437.

62 Matsushita H, Ishihara A, Mashiko S, Tanaka T, Kanno T, Iwaasa H, Ohta H, Kanatani A: Chronic intracerebroventricular infusion of nociceptin/orphanin FQ produces body weight gain by affecting both feeding and energy metabolism. Endocrinology 2009;150: 2668-2673.

63 Leventhal L, Mathis JP, Rossi GC, Pasternak GW, Bodnar RJ: Orphan opioid receptor antisense probes block orphanin FQ-induced hyperphagia. Eur J Pharmacol 1998;349:R1R3.

64 Bomberg EM, Grace MK, Levine AS, Olszewski PK: Functional interaction between nociceptin/orphanin FQ and a-melanocytestimulating hormone in the regulation of feeding. Peptides 2006;27:1827-1834.

65 Butera PC, Czaja JA: Intracranial estradiol in ovariectomized guinea pigs: effects on ingestive behaviors and body weight. Brain Res 1984;322:41-48.

66 Dubuc PU: Effects of estrogen on food intake, body weight and temperature of male and female obese mice. Proc Soc Exp Biol Med 1985; 180:468-473.
67 Palmer K, Gray JM: Central vs. peripheral effects of estrogen on food intake and lipoprotein lipase activity in ovariectomized rats. Physiol Behav 1986;37:187-189.

68 Johnson WG, Corrigan SA, Lemmon CR, Bergeron KB, Crusco AH: Energy regulation over the menstrual cycle. Physiol Behav 1994; 56:523-527.

69 Moore KE: Hypothalamic dopaminergic neuronal systems; in Meltzer HY (ed): Psychopharmacology: The Third Generation of Progress. New York, Raven Press, 1987, vol 127-139.

70 Shieh K-R, Pan J-T: Effects of orphanin FQ on central dopaminergic neuronal activities and prolactin secretion. Am J Physiol Regul Integr Comp Physiol 2001;280:R705-R712.

-71 An X-F, Chen H-P, Ma S-L, Feng Y, Hao J-W, Chen B-Y: Involvement of nociceptin/orphanin FQ in release of hypothalamic GnRH mediated by ORL1 receptor in ovariectomized rats. Acta Pharmacol Sin 2005;26: 1039-1044.

72 An X-F, Yu J-Y, Chen B-Y, Zhang S-L: Role of hypothalamus nociceptin/orphanin FQ in pre-ovulatory luteinizing hormone surge of estrogen and progesterone-primed, ovariectomized rats. Acta Pharmacol Sin 2007;28: 1189-1197. 